\title{
Modeling Hydrocarbon Generation of Deeply Buried Type III Kerogen: A Study on Gas and Oil Potential of Lishui Sag, East China Sea Shelf Basin
}

\author{
Jinliang Zhang ${ }^{1}$, Yang $L i^{1 *}$, Jinshui Liu ${ }^{2}$, Xue Yan ${ }^{1}$, Lianjie $L i^{1}$ and Wenlong Shen ${ }^{2}$ \\ ${ }^{1}$ Faculty of Geographical Science, Beijing Normal University, Beijing, China, ${ }^{2}$ CNOOC China Ltd., Shanghai, China
}

\section{OPEN ACCESS}

Edited by:

Dawei Lv,

Shandong University of Science and

Technology, China

Reviewed by:

Dong Wu,

Chengdu University of Technology,

China

Wang Yougong,

Northeast Petroleum University, China

*Correspondence:

Yang $\mathrm{Li}$

lyugly@163.com

Specialty section:

This article was submitted to Sedimentology, Stratigraphy and

Diagenesis,

a section of the journa

Frontiers in Earth Science

Received: 24 September 2020

Accepted: 22 December 2020

Published: 29 January 2021

Citation:

Zhang J, Li Y, Liu J, Yan X, Li L and Shen W (2021) Modeling Hydrocarbon Generation of Deeply Buried Type III

Kerogen: A Study on Gas and Oil Potential of Lishui Sag, East China Sea

Shelf Basin.

Front. Earth Sci. 8:609834. doi: 10.3389/feart.2020.609834
The hydrocarbon generation model and hydrocarbon potential are investigated in the Lishui Sag, based on gold-tube pyrolysis experiments of deeply buried type III kerogen. From this, we discuss the classification of kerogen types of source rocks with mixed organic matter sources. The hydrocarbon generated from the source rocks of the Lingfeng Formation and Yueguifeng Formation is dominated by natural gases with little oil in the West subsag, and the hydrocarbon generation model of the Lingfeng Formation is similar to that of Yueguifeng Formation, but the gas potential of Lingfeng Formation is higher than that of Yueguifeng Formation. The hydrocarbon potential of the Yueguifeng Formation in the East subsag is much higher than the West subsag, and it has considerable oil potential. Macerals diversity of source rocks is responsible for the difference of hydrocarbon generation characteristics for type III kerogen in the Lishui Sag. It is not rigorous to evaluate the hydrocarbon potential of kerogen only based on pyrolysis parameters. Application of kerogen type index (KTI) can improve the accuracy of the classification of kerogen types with mixed organic matter sources. According to the classical kerogen classification template, the selected samples belong to type III kerogen. In this article, the selected samples were further subdivided into type III and type II/III based on the KTI value. Type III kerogen $(0.5 \leq \mathrm{KTI}<1.5)$ mainly produces gas, and type I/III kerogen $(1.5 \leq \mathrm{KTI}<5)$ mainly produces gas, but its oil potential is higher than that of type III.

Keywords: source rock, gold tube pyrolysis, kerogen, modeling hydrocarbon generation, hydrocarbon potential

\section{INTRODUCTION}

Comprehensive evaluation of source rocks is the basis of oil and gas potential of a sedimentary basin, and hydrocarbon generation simulation of source rocks becomes an important part of oil and gas exploration. The hydrocarbon generation model of source rocks is closely related to the types of kerogen, and the chart based on rock pyrolysis parameters proposed by Tissot and Welte is usually used to divide the types of kerogen (Tissot and Welte, 1984). The term kerogen represents the organic constituent of the sedimentary rocks that is neither soluble in aqueous alkaline solvents nor in the common organic solvents (Tissot and Welte, 1984). Kerogen is widely accepted as the source material of hydrocarbon and the hydrocarbon generation model of kerogen proposed by Tissot points out that type I kerogen is mainly deposited in lake environment and mainly generates oil; type II kerogen is deposited in marine environment with oil and gas dipping properties; and type III kerogen is a kind of gas dipping organic matter deposited in continental environment. However, with the development of 
oil and gas exploration to deep and unconventional fields and the deepening of kerogen hydrocarbon generation simulation research, the Tissot model shows some limitations (Li et al., 2018; Agrawal and Sharma, 2020). The discovery of type III kerogen in delta plain deposits, which is dominated by oil generation, also indicates that the type of kerogen cannot determine the type of hydrocarbon generation (Agrawal and Sharma, 2020). Based on the hydrocarbon generation simulation experiments, the diversity of kerogen types is the main reason for the difference of hydrocarbon generation modes of source rocks (Tissot, 1984; Dembicki, 2009). Even then, due to the different sedimentary environment, source and evolution of organic matter of source rocks in different basins, the same type of kerogen has its own hydrocarbon generation characteristics (Horsfield, 1989; Liu et al., 2012). Therefore, in order to judge the hydrocarbon generation potential of a basin, it is not enough to just know the organic matter types of the source rocks. In recent years, most of the hydrocarbon generation and expulsion simulation experiments for source rocks in various basins have focused on the hydrocarbon generation characteristics of coal, type I and type II kerogen, and crude oil cracking, while there is little relevant research on hydrocarbon generation and expulsion simulation of type III kerogen (Jasper et al., 2009; Tian et al., 2009; Tian et al., 2012; Wang et al., 2014; Hill et al., 2003). Meanwhile, more and more hydrocarbon generating sags with type III kerogen as the main organic matter type have been found such as Xihu Sag and Lishui Sag in the East China Sea Shelf basin (ECSSB) (Su et al., 2013; Cheng et al., 2019; Li et al., 2019).

The Lishui Sag has a low degree of exploration and is located at the gateway of developing oil and gas resources in the ECSSB (Chen et al., 2008; Su et al., 2014; Li et al., 2016; Zhang et al., 2019; Liu et al., 2020; Sun et al., 2020). Up to now, one oil-gas field and six oil-bearing structures have been discovered, indicating that it has certain exploration potential. However, only fluorescence and gas logging anomalies have been obtained in five wells (Zhang et al., 2015; Li et al., 2020). It is considered that the insufficient hydrocarbon supply capacity of local subsags is one of the main failure reasons. Therefore, it is necessary to re-evaluate the hydrocarbon generation potential of source rocks in each subsag (Shen et al., 2019). The Lishui Sag is a typical hydrocarbon bearing depression with type III kerogen as the main kerogen type of source rocks, which is representative in the ECSSB (Li et al., 2019). Therefore, the study of hydrocarbon generation and hydrocarbon potential of type III kerogen in Lishui Sag has significance to the evaluation of oil and gas potential of other sags in the basin. In this research, the model of hydrocarbon generation of type III kerogen in mature stage under deep buried conditions is studied by gold tube pyrolysis experiments. The reasons for the difference of hydrocarbon generation characteristics are discussed. In addition, the hydrocarbon generation potential of source rocks in different layers of the Lishui Sag is evaluated.

\section{GEOLOGICAL BACKGROUND}

The Lishui Sag is located in the southwest of Taibei basin in the ECSSB and adjacent to Jiaojiang sag in the north. It is a Cenozoic single fault half graben depression formed on the basement of Mesozoic residual basin. The Lishui Sag is divided into two subsags, the East subsag and the West subsag, with an area of $1.46 \times 10^{4} \mathrm{~km}^{2}$ (Figure 1A). The area of East subsag is about $4.8 \times$ $10^{3} \mathrm{~km}^{2}$, and the maximum deposit thickness is more than $7.5 \mathrm{~km}$; the area of West subsag is about $9.8 \times 10^{3} \mathrm{~km}^{2}$, and the maximum deposit thickness is $12 \mathrm{~km}$. The faults in Lishui Sag are mainly NNE-NE trending. From west to east, the faults can be divided into four structural zones: western slope structural zone, central inversion structural zone, Lingfeng ridge, and Eastern step-fault zone (Figure 1B; Ge et al., 2007). In Lishui Sag, oil and gas are mainly discovered in the Paleocene. The main source rocks are the mudstones in lower Paleocene Yueguifeng $\left(\mathrm{E}_{1} \mathrm{y}\right)$ Formation and overlying Lingfeng $\left(\mathrm{E}_{1} \mathrm{l}\right)$ Formation. The Mingyuefeng Formation $\left(\mathrm{E}_{1} \mathrm{~m}\right)$ is the main reservoir (Figure 1C; Li et al., 2019). The main source rocks in Lishui Sag are deeply buried (more than $3 \mathrm{~km}$ ) and have reached mature stage. Some source rocks in the $\mathrm{E}_{1} \mathrm{y}$ formation buried more than $4 \mathrm{~km}$ deep have reached the over mature stage. The kerogen types of source rocks in Lishui Sag are relatively simple. According to the classical classification chart of kerogen types, more than $86 \%$ of the source rocks are type III, which provides a good sample condition for exploring the hydrocarbon generation characteristics of typical type III kerogen in this article (Chen et al., 2008; Su et al., 2014; Li et al., 2019).

\section{MATERIALS AND METHODS}

\section{Samples Selection and Preparation}

As mentioned above, the hydrocarbon generation characteristics of source rocks are greatly affected by organic matter type, sedimentary environment, and maturity, so the above factors should be fully considered when selecting samples. In view of the limited number of wells in the Lishui Sag, and the burial depth of source rock, the well location with good oil and gas displaying the source rock of $E_{1} y$ formation should be selected as the sampling well. Secondly, considering the influence of heterogeneity of source rock at the same layer, single subsag should not be selected for sampling well. At the same time, due to the differences in sedimentary environment, the source rocks of the $E_{1} y$ and $E_{1} l$ formations should be sampled. The samples selected in this experiment are mudstones of the $E_{1} l$ formation and $\mathrm{E}_{1} \mathrm{y}$ formation in LD well in the West subsag, and the organic matter type is typical type III kerogen, which is representative in the whole area. Meanwhile, mudstones of the $E_{1} y$ formation in W1 well of the East subsag are selected for comparative study (Figure 2). Due to the burial depth, the three mudstone samples have reached the mature stage. In order to avoid the influence of maturity in the same layer, the vitrinite reflectance (Ro) of the samples from the $\mathrm{E}_{1} \mathrm{y}$ formation has little difference. The source rocks in the Lishui Sag are mainly type III kerogen and are mostly gray or gray-black mudstone, and their TOC is relatively low. Therefore, in order to ensure the validity and accuracy of the experimental results, the kerogen was selected instead of source rock for hydrocarbon generation simulation experiment. The preparation process of kerogen is as follows: Soxhlet extracting 


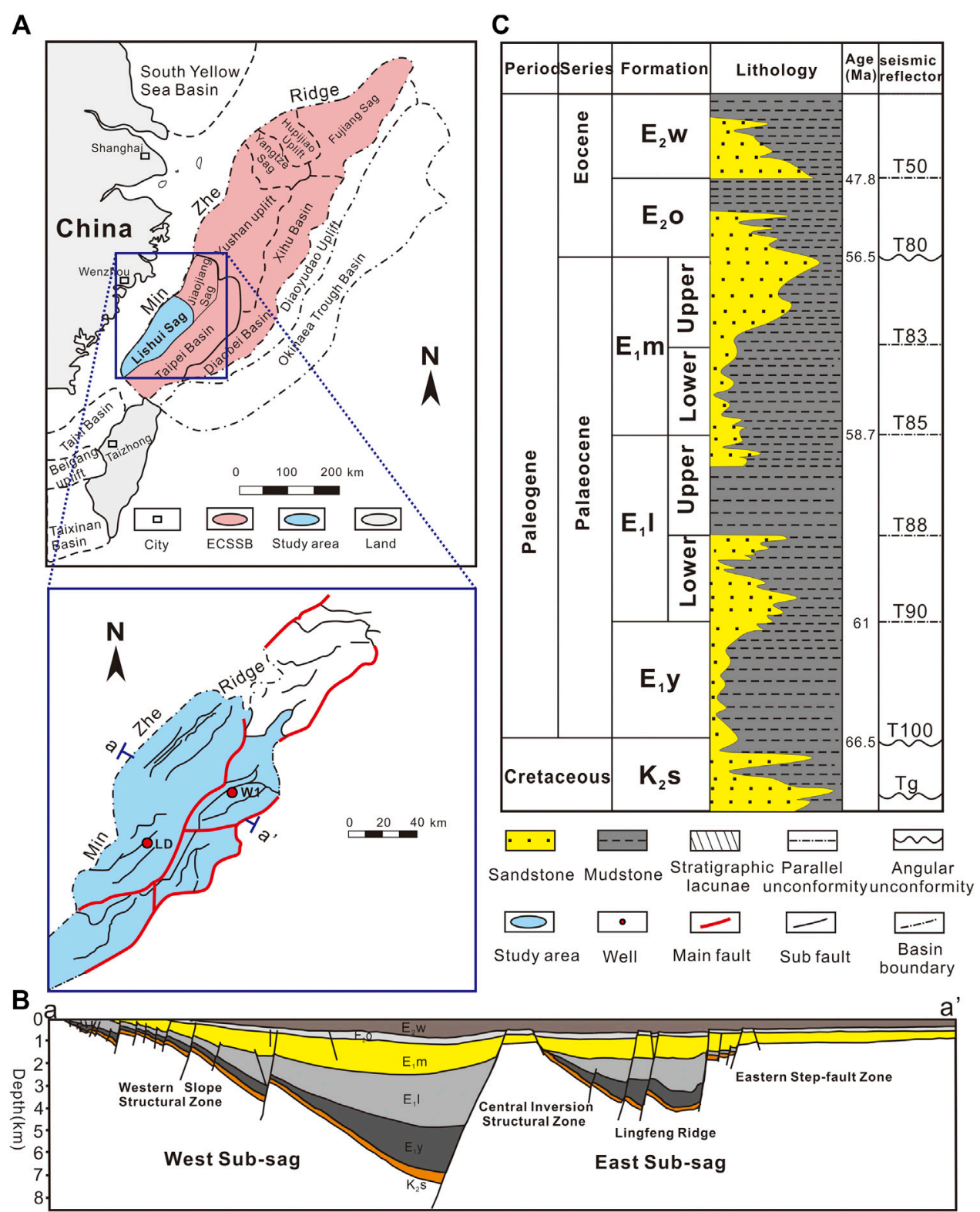

FIGURE 1 | Geographical location (A), structural features (B), and stratigraphic column (C) of the Lishui Sag.

mudstone powder $(0.5 \mathrm{~kg})$ for $72 \mathrm{~h}$; adding dilute hydrochloric acid with a mass fraction of $20 \%$ to the extracted sample, and heating the sample in a water bath at $80^{\circ} \mathrm{C}$ for $4 \mathrm{~h}$; after no bubbles are generated, the supernatant is decanted by centrifugation; adding hydrofluoric acid and repeating the above steps; adding distilled water several times to remove inorganic salt, and finally drying in an oven at $80^{\circ} \mathrm{C}$ to obtain the separated kerogen. The basic information of samples is shown in Table 1.

\section{Experimental Process and Conditions}

At present, simulation experiments of hydrocarbon generation of source rocks can be divided into open systems, semiopen systems, and closed systems (Behar et al., 1995; Tang et al., 1996;
Dieckmann et al., 1998; Dieckmann et al., 2000; Zhang et al., 2008; Bayon et al., 2011; Wang et al., 2011; Hartwig et al., 2012.; Xu et al., 2020). Previous experiments show that the products of simulation experiments of hydrocarbon generation in closed system are closer to the hydrocarbon generating components of source rocks under geological conditions (Zhang et al., 2008). In this study, the gold tube pyrolysis experiment was carried out in a closed system and the experimental process and conditions are as follows: the kerogen sample was sealed into gold tube with inner diameter of 3 and $40 \mathrm{~mm}$ in length under the protection of argon and placed in an autoclave with a pressure of $50 \mathrm{MPa}$ (Tang et al., 1996; Ruble et al., 2001; Hill et al., 2007; Zhang et al., 2008). Each sample was divided into two groups (12 in each group) and 


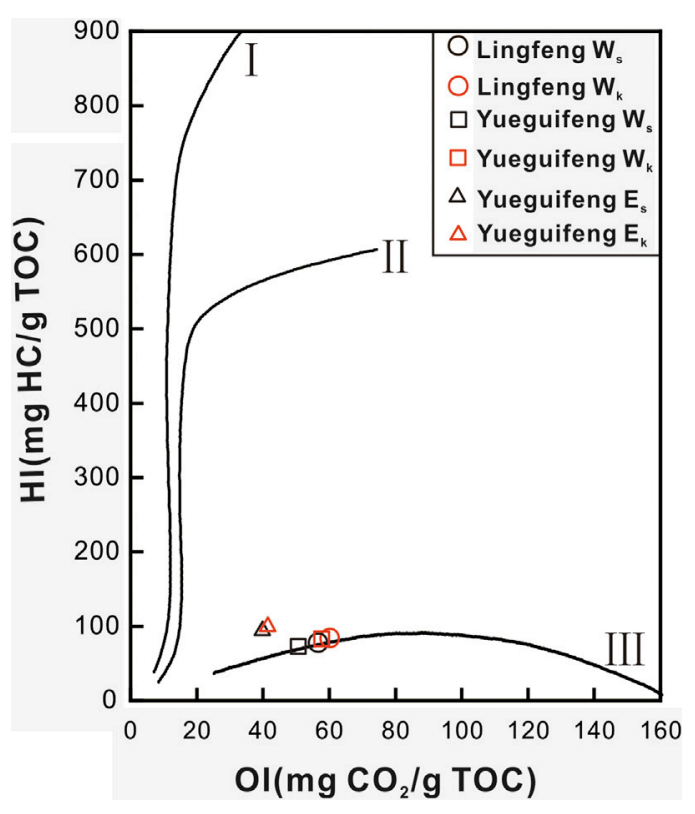

FIGURE 2 | Kerogen type classification of the selected samples. Note: $W_{\mathrm{s}}$, source rock in the West subsag; $W_{k}$, corresponding kerogen in the West subsag; $E_{s}$, source rock in the East subsag; $E_{k}$, corresponding kerogen in the East subsag.

heated from room temperature to the required temperature at the heating rate of $2^{\circ} \mathrm{C} / \mathrm{h}$ and $20^{\circ} \mathrm{C} / \mathrm{h}$, respectively, and the temperature interval was $24^{\circ} \mathrm{C}$. Because water participates in the maturation process and expulsion of hydrocarbon in source rocks under geological conditions (Seewald, 2003; Lewan and Roy, 2011), and it has an important impact on the thermal stability of source rocks (Ruble et al., 2003), in our gold tube pyrolysis experiment a fixed amount of distilled water (about $15 \%$ of the sample weight) is added to each sample. After the thermal simulation experiment, qualitative and quantitative analysis of gases (including nonhydrocarbon gas) and carbon isotope analysis of hydrocarbon gas $\left(\mathrm{C}_{1}-\mathrm{C}_{3}\right)$ and $\mathrm{CO}_{2}$ were carried out. The light component $\left(\mathrm{C}_{6}-\mathrm{C}_{14}\right)$ of thermal simulation oil was qualitatively and quantitatively analyzed by gas chromatography, and the heavy component $\left(\mathrm{C}_{14}{ }^{+}\right)$of thermal simulation oil was analyzed by organic extraction and weighing. The whole components of thermal simulation oil were analyzed by Gas Chromatography-Mass Spectrometry (GC-MS), and the yield and kinetic parameters of hydrocarbon generation were calculated. At the end of the experiment, the kinetic parameters of hydrocarbon generation, thermal simulation gas production, and isotope data of each component of each sample can be obtained.

\section{RESULTS}

\section{Hydrocarbon Generation Model}

Because the selected samples have entered the mature stage, the starting temperature for the simulation experiment of hydrocarbon generation in gold tube is $350^{\circ} \mathrm{C}$, which is used to simulate the present maturity and the hydrocarbon generation characteristics. In this experiment, a four-component model is adopted. $\mathrm{C}_{1}$ represents methane, $\mathrm{C}_{2}-\mathrm{C}_{5}$ represents heavy hydrocarbon gases, $\mathrm{C}_{6}-\mathrm{C}_{14}$ represents light oil components, and $\mathrm{C}_{14}{ }^{+}$represents heavy oil components, where $\mathrm{C}_{1}-\mathrm{C}_{5}$ represents natural gas components and $\mathrm{C}_{6}{ }^{+}$represents oil components. According to the simulation results, it can be seen that, under different heating rates, the simulated temperatures at which hydrocarbon generation products begin to generate and decrease are slightly different (Figure 3).

As shown in Table 2, under a heating rate of $20^{\circ} \mathrm{C} / \mathrm{h}$, the methane yield of Lingfeng Formation in the West subsag increases rapidly at $432^{\circ} \mathrm{C}(R o=1.19)$, and the maximum methane yield reaches $91.97 \mathrm{mg} / \mathrm{g}$ TOC when the temperature reaches $599.8^{\circ} \mathrm{C}(R o=3.87)$. The yield of heavy hydrocarbon gases increases at $408^{\circ} \mathrm{C}(R o=0.96)$. When the temperature reaches $481.7^{\circ} \mathrm{C}(R o=1.19)$, the yield of heavy hydrocarbon gases reaches the maximum value of $8.48 \mathrm{mg} / \mathrm{g}$ TOC. With the increase of temperature, the yield of heavy hydrocarbon gases begins to decrease, and the methane yield increases sharply. When the temperature reaches $551.8^{\circ} \mathrm{C}(R o=3.06)$, the yield of heavy hydrocarbon gases is close to zero, and methane is the main hydrocarbon generating gas. The maximum yields of heavy oil and light oil components are $8.15 \mathrm{mg} / \mathrm{g}$ TOC and $14.36 \mathrm{mg} / \mathrm{g}$ TOC, respectively, at $456.5^{\circ} \mathrm{C}(R o=1.50)$. The yield of heavy oil

\begin{tabular}{|c|c|c|c|c|c|c|c|}
\hline Sample & Well & $\begin{array}{c}\text { Depth } \\
\text { (m) }\end{array}$ & Formation & $\begin{array}{c}\text { TOC } \\
(\%)\end{array}$ & $\begin{array}{l}\text { Ro } \\
\text { (\%) }\end{array}$ & $\begin{array}{c}\mathrm{HI} \\
(\mathrm{mg} / \mathrm{g})\end{array}$ & $\begin{array}{c}\text { Ol } \\
(\mathrm{mg} / \mathrm{g})\end{array}$ \\
\hline $\begin{array}{l}\text { Source } \\
\text { rock }\end{array}$ & LD & 3334.00 & $E_{1} l$ & 1.84 & 0.82 & 83.70 & 58.70 \\
\hline Kerogen & LD & 3334.00 & $E_{1} I$ & 9.33 & & 89.92 & 61.31 \\
\hline $\begin{array}{l}\text { Source } \\
\text { rock }\end{array}$ & LD & 3759.50 & $\mathrm{E}_{1} \mathrm{y}$ & 2.96 & 0.94 & 79.05 & 52.70 \\
\hline Kerogen & LD & 3759.50 & $E_{1} y$ & 13.13 & & 88.12 & 59.86 \\
\hline $\begin{array}{l}\text { Source } \\
\text { rock }\end{array}$ & W1 & 3813.00 & $E_{1} y$ & 2.49 & 0.95 & 103.61 & 41.37 \\
\hline Kerogen & W1 & 3813.00 & $E_{1} y$ & 27.66 & & 108.03 & 43.24 \\
\hline
\end{tabular}

components is close to zero when the temperature is higher than $551.8^{\circ} \mathrm{C}(R o=3.06)$, and the yield of light oil components is close to zero when the temperature is higher than $575.8^{\circ} \mathrm{C}(R o=3.50)$. At this time, the main hydrocarbon generation product is methane (Figure 3A). Under a heating rate of $2^{\circ} \mathrm{C} / \mathrm{h}$, the methane yield of the Lingfeng Formation in the West subsag increases rapidly at $384^{\circ} \mathrm{C}(R o=1.08)$ and reaches $96.3 \mathrm{mg} / \mathrm{g}$ TOC when the temperature reaches $578^{\circ} \mathrm{C}(R o=4.22)$. With the increase of temperature, the yield tends to be stable. When the temperature reaches $442^{\circ} \mathrm{C}(R o=1.85)$, the yield of heavy hydrocarbon gases reaches the maximum value of $9.06 \mathrm{mg} / \mathrm{g}$ TOC. With the increase of temperature, the yield of heavy hydrocarbon gases begins to decrease. When the temperature reaches $540^{\circ} \mathrm{C}(R o=3.67)$, the yield of heavy hydrocarbon gases is close to zero. The maximum yields of heavy oil and light oil 

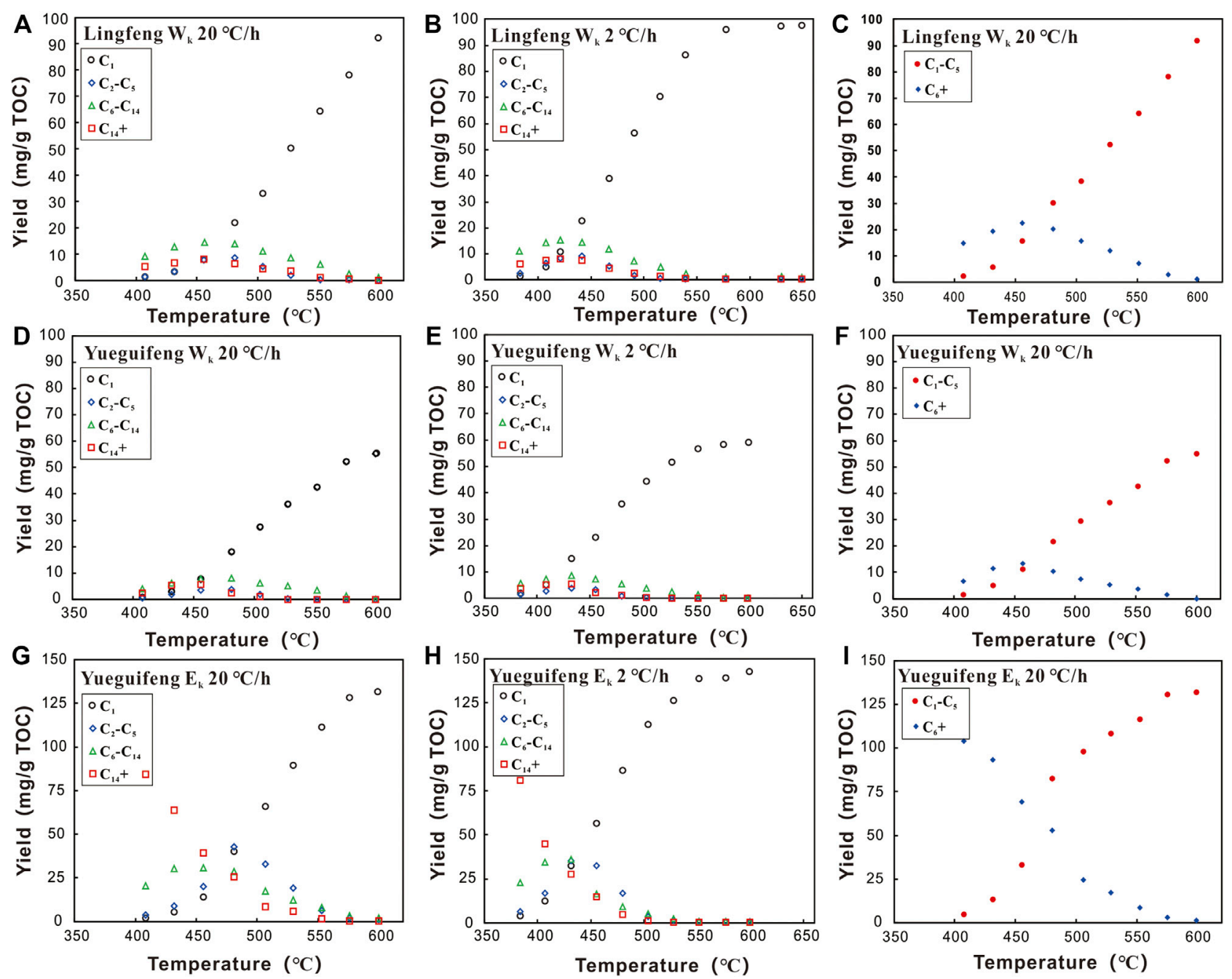

FIGURE 3 | Hydrocarbon generation characteristics of kerogen in source rocks of Lishui Sag under two heating rates.

components are $7.93 \mathrm{mg} / \mathrm{g}$ TOC and $14.90 \mathrm{mg} / \mathrm{g}$ TOC, respectively, at $422^{\circ} \mathrm{C}(R o=1.55)$. When the temperature is higher than $516^{\circ} \mathrm{C}(R o=3.22)$, the yield of heavy oil components is close to zero, and the yield of light oil components is close to zero when the temperature is higher than $540^{\circ} \mathrm{C}(R o=3.67)$ (Figure 3B). If the hydrocarbon generating components are divided into natural gas and oil components, the sample of Lingfeng Formation in the West subsag generates oil slightly earlier than gas under the heating rate of $20^{\circ} \mathrm{C} / \mathrm{h}$ and reaches the maximum yield at $456.5^{\circ} \mathrm{C}(R o=$ $1.50)$ and then starts cracking to form natural gas. When the temperature reaches $599.8^{\circ} \mathrm{C}(R o=3.87)$, the maximum yield of natural gas is achieved (Figure $3 \mathrm{C}$ ).

Under a heating rate of $20^{\circ} \mathrm{C} / \mathrm{h}$, the methane yield of Yueguifeng Formation in West subsag begins to increase rapidly at $432^{\circ} \mathrm{C}(R o=1.19)$. When the temperature reaches $599.8^{\circ} \mathrm{C}(R o=3.87)$, the maximum methane yield reaches $55.13 \mathrm{mg} / \mathrm{g}$ TOC. When the temperature reaches $481.7^{\circ} \mathrm{C}$ $(R o=1.84)$, the yield of heavy hydrocarbon gases reaches the maximum value of $3.77 \mathrm{mg} / \mathrm{g}$ TOC. With the increase of temperature, the yield of heavy hydrocarbon gases begins to decrease. When the temperature reaches $528.1^{\circ} \mathrm{C}(R o=2.62)$, the yield of heavy hydrocarbon gases is close to zero. The maximum yield of heavy oil and light oil components are $2.36 \mathrm{mg} / \mathrm{g}$ Toc and $8.07 \mathrm{mg} / \mathrm{g}$ TOC at $481.7^{\circ} \mathrm{C}(R o=1.84)$ (Figure 3D). Under the heating rate of $2^{\circ} \mathrm{C} / \mathrm{h}$, the methane yield of Yueguifeng Formation in the West subsag begins to increase rapidly at $408.3^{\circ} \mathrm{C}(R o=1.36)$, and the maximum methane yield reaches $58.89 \mathrm{mg} / \mathrm{g}$ TOC when the temperature reaches $599.1^{\circ} \mathrm{C}(R o=4.45)$. When the temperature is $432.6^{\circ} \mathrm{C}$ $(R o=1.69)$, the heavy hydrocarbon gases yield reaches the maximum value of $3.97 \mathrm{mg} / \mathrm{g}$ TOC. With temperature continuous increase to $551.9^{\circ} \mathrm{C}(R o=3.86)$, the heavy hydrocarbon gases yield is close to zero. The maximum yield of heavy oil components is $5.48 \mathrm{mg} / \mathrm{g}$ TOC at $432.6^{\circ} \mathrm{C}(R o=1.69)$, and the maximum yield of light oil components is $8.61 \mathrm{mg} / \mathrm{g}$ TOC at $432.6^{\circ} \mathrm{C}(R o=1.69)$. The yield of light oil components is higher than that of heavy oil components (Figure 3E). The time of oil 
TABLE 2 | Yield and carbon isotope data of different compositions by gold tube hydrocarbon generation simulation experiment.

\begin{tabular}{|c|c|c|c|c|c|c|c|c|c|}
\hline ID & $\begin{array}{c}\text { Temperature } \\
{ }^{\circ} \mathbf{C}\end{array}$ & $\begin{array}{c}\text { Heating } \\
\text { rate } \\
{ }^{\circ} \mathrm{C} / \mathrm{h}\end{array}$ & $\begin{array}{c}\text { easyRo } \\
\%\end{array}$ & $\begin{array}{c}\mathrm{C}_{1} \mathrm{mg} / \mathrm{g} \\
\text { TOC }\end{array}$ & $\begin{array}{c}\mathrm{C}_{1}-\mathrm{C}_{5} \mathrm{mg} / \mathrm{g} \\
\text { TOC }\end{array}$ & $\begin{array}{c}\mathrm{C}_{2}-\mathrm{C}_{5} \mathrm{mg} / \mathrm{g} \\
\text { TOC }\end{array}$ & $\begin{array}{c}\mathrm{C}_{6}-\mathrm{C}_{14} \mathrm{mg} / \mathrm{g} \\
\text { TOC }\end{array}$ & $\begin{array}{c}\mathrm{C}_{14+} \mathrm{mg} / \mathrm{g} \\
\text { TOC }\end{array}$ & $\begin{array}{c}\mathrm{C}_{6+} \\
\mathrm{mg} / \mathrm{g} \\
\mathrm{TOC}\end{array}$ \\
\hline$W L-1$ & 408.00 & 20 & 0.96 & 0.92 & 2.22 & 1.30 & 9.22 & 5.36 & 14.68 \\
\hline WL-2 & 432.00 & 20 & 1.19 & 2.61 & 5.80 & 3.19 & 12.65 & 6.75 & 19.29 \\
\hline WL-3 & 456.50 & 20 & 1.50 & 7.90 & 15.73 & 7.83 & 14.36 & 8.15 & 22.51 \\
\hline WL-4 & 481.70 & 20 & 1.84 & 21.79 & 30.27 & 8.48 & 13.93 & 6.32 & 20.26 \\
\hline WL-5 & 504.70 & 20 & 2.23 & 33.00 & 38.30 & 5.30 & 11.15 & 4.39 & 15.54 \\
\hline WL-6 & 528.10 & 20 & 2.62 & 50.27 & 52.23 & 1.96 & 8.57 & 3.43 & 12.11 \\
\hline WL-7 & 551.80 & 20 & 3.06 & 63.93 & 64.22 & 0.29 & 6.00 & 1.18 & 7.18 \\
\hline WL-8 & 575.80 & 20 & 3.50 & 78.05 & 78.19 & 0.15 & 2.36 & 0.43 & 2.79 \\
\hline WL-9 & 599.80 & 20 & 3.87 & 91.97 & 91.97 & 0.00 & 1.18 & 0.00 & 1.18 \\
\hline $\begin{array}{l}\text { WL- } \\
10\end{array}$ & 384.00 & 2 & 1.08 & 1.69 & 3.93 & 2.24 & 10.93 & 6.00 & 16.93 \\
\hline $\begin{array}{l}\text { WL- } \\
11\end{array}$ & 408.00 & 2 & 1.35 & 4.83 & 11.14 & 6.30 & 14.47 & 7.29 & 21.76 \\
\hline $\begin{array}{l}\text { WL- } \\
12\end{array}$ & 422.00 & 2 & 1.55 & 10.51 & 18.62 & 8.11 & 14.90 & 7.93 & 22.83 \\
\hline $\begin{array}{l}\text { WL- } \\
13\end{array}$ & 442.00 & 2 & 1.85 & 22.56 & 31.62 & 9.06 & 14.15 & 7.18 & 21.33 \\
\hline $\begin{array}{l}\text { WL- } \\
14\end{array}$ & 468.00 & 2 & 2.30 & 38.60 & 43.75 & 5.15 & 11.58 & 4.39 & 15.97 \\
\hline $\begin{array}{l}\text { WL- } \\
15\end{array}$ & 492.00 & 2 & 2.76 & 56.02 & 57.55 & 1.52 & 7.07 & 2.47 & 9.54 \\
\hline $\begin{array}{l}\text { WL- } \\
16\end{array}$ & 516.00 & 2 & 3.22 & 70.37 & 70.81 & 0.44 & 4.82 & 1.29 & 6.11 \\
\hline $\begin{array}{l}\text { WL- } \\
17\end{array}$ & 540.00 & 2 & 3.67 & 86.10 & 86.25 & 0.15 & 2.25 & 0.32 & 2.57 \\
\hline $\begin{array}{l}\text { WL- } \\
18\end{array}$ & 578.00 & 2 & 4.22 & 96.16 & 96.30 & 0.15 & 0.64 & 0.11 & 0.75 \\
\hline $\begin{array}{l}\text { WL- } \\
19\end{array}$ & 630.00 & 2 & 4.66 & 97.10 & 97.10 & 0.00 & 0.00 & 0.00 & 0.00 \\
\hline $\begin{array}{l}W L- \\
20\end{array}$ & 650.00 & 2 & 4.90 & 97.32 & 97.32 & 0.00 & 0.00 & 0.00 & 0.00 \\
\hline$W Y-1$ & 408.00 & 20 & 0.96 & 0.93 & 1.60 & 0.67 & 4.19 & 2.44 & 6.63 \\
\hline WY-2 & 432.00 & 20 & 1.19 & 3.11 & 5.01 & 1.91 & 6.25 & 5.33 & 11.58 \\
\hline$W Y-3$ & 456.50 & 20 & 1.50 & 7.69 & 11.24 & 3.55 & 7.84 & 5.56 & 13.40 \\
\hline$W Y-4$ & 481.70 & 20 & 1.84 & 18.00 & 21.76 & 3.77 & 8.07 & 2.36 & 10.43 \\
\hline WY-5 & 504.70 & 20 & 2.23 & 27.37 & 29.39 & 2.01 & 6.32 & 1.14 & 7.46 \\
\hline WY-6 & 528.10 & 20 & 2.62 & 35.99 & 36.40 & 0.41 & 5.10 & 0.15 & 5.26 \\
\hline$W Y-7$ & 551.80 & 20 & 3.06 & 42.59 & 42.59 & 0.00 & 3.66 & 0.00 & 3.66 \\
\hline WY-8 & 575.80 & 20 & 3.50 & 52.24 & 52.39 & 0.00 & 1.37 & 0.00 & 1.37 \\
\hline WY-9 & 599.80 & 20 & 3.87 & 55.13 & 55.13 & 0.00 & 0.00 & 0.00 & 0.00 \\
\hline $\begin{array}{l}\text { WY- } \\
10\end{array}$ & 384.40 & 2 & 1.08 & 1.96 & 3.41 & 1.44 & 5.71 & 3.88 & 9.60 \\
\hline $\begin{array}{l}\text { WY- } \\
11\end{array}$ & 408.30 & 2 & 1.36 & 4.91 & 7.69 & 2.78 & 7.46 & 5.33 & 12.95 \\
\hline $\begin{array}{l}W Y- \\
12\end{array}$ & 432.60 & 2 & 1.69 & 15.11 & 19.07 & 3.97 & 8.61 & 5.48 & 14.09 \\
\hline $\begin{array}{l}\text { WY- } \\
13\end{array}$ & 455.30 & 2 & 2.05 & 23.18 & 26.38 & 3.20 & 7.39 & 2.28 & 9.67 \\
\hline $\begin{array}{l}\text { WY- } \\
14\end{array}$ & 479.60 & 2 & 2.52 & 35.77 & 36.81 & 1.03 & 5.48 & 1.29 & 6.78 \\
\hline $\begin{array}{l}\text { WY- } \\
15\end{array}$ & 503.10 & 2 & 2.99 & 44.33 & 44.75 & 0.41 & 3.88 & 0.30 & 4.19 \\
\hline $\begin{array}{l}\text { WY- } \\
16\end{array}$ & 527.10 & 2 & 3.42 & 51.64 & 51.85 & 0.21 & 2.44 & 0.15 & 2.59 \\
\hline $\begin{array}{l}\text { WY- } \\
17\end{array}$ & 551.90 & 2 & 3.86 & 56.82 & 56.93 & 0.10 & 1.52 & 0.08 & 1.60 \\
\hline $\begin{array}{l}\text { WY- } \\
18\end{array}$ & 576.00 & 2 & 4.19 & 58.40 & 58.40 & 0.00 & 0.38 & 0.00 & 0.38 \\
\hline $\begin{array}{l}\text { WY- } \\
19\end{array}$ & 599.10 & 2 & 4.45 & 58.89 & 58.89 & 0.00 & 0.00 & 0.00 & 0.00 \\
\hline EY-1 & 408.10 & 20 & 0.96 & 1.71 & 4.96 & 3.26 & 19.96 & 83.91 & 103.87 \\
\hline EY-2 & 432.00 & 20 & 1.19 & 5.10 & 13.38 & 8.28 & 29.86 & $\begin{array}{l}63.52 \\
\text { tinued on follc }\end{array}$ & $\begin{array}{c}93.38 \\
\text { page) }\end{array}$ \\
\hline
\end{tabular}


TABLE 2 | (Continued) Yield and carbon isotope data of different compositions by gold tube hydrocarbon generation simulation experiment.

\begin{tabular}{|c|c|c|c|c|c|c|c|c|c|}
\hline ID & $\begin{array}{c}\text { Temperature } \\
{ }^{\circ} \mathbf{C}\end{array}$ & $\begin{array}{c}\text { Heating } \\
\text { rate } \\
{ }^{\circ} \mathrm{C} / \mathrm{h}\end{array}$ & $\begin{array}{c}\text { easyRo } \\
\%\end{array}$ & $\begin{array}{c}\mathrm{C}_{1} \mathrm{mg} / \mathrm{g} \\
\text { TOC }\end{array}$ & $\begin{array}{c}\mathrm{C}_{1}-\mathrm{C}_{5} \mathrm{mg} / \mathrm{g} \\
\text { TOC }\end{array}$ & $\begin{array}{c}\mathrm{C}_{2}-\mathrm{C}_{5} \mathrm{mg} / \mathrm{g} \\
\text { TOC }\end{array}$ & $\begin{array}{c}\mathrm{C}_{6}-\mathrm{C}_{14} \mathrm{mg} / \mathrm{g} \\
\text { TOC }\end{array}$ & $\begin{array}{c}\mathrm{C}_{14+} \mathrm{mg} / \mathrm{g} \\
\text { TOC }\end{array}$ & $\begin{array}{c}\mathrm{C}_{6+} \\
\mathrm{mg} / \mathrm{g} \\
\mathrm{TOC}\end{array}$ \\
\hline EY-3 & 456.00 & 20 & 1.47 & 13.59 & 33.25 & 19.66 & 30.30 & 38.79 & 69.09 \\
\hline$E Y-4$ & 481.20 & 20 & 1.81 & 39.76 & 82.29 & 42.53 & 28.02 & 24.98 & 53.00 \\
\hline EY-5 & 506.60 & 20 & 2.19 & 65.67 & 97.98 & 32.31 & 16.85 & 7.88 & 24.73 \\
\hline EY-6 & 529.50 & 20 & 2.54 & 89.28 & 108.19 & 18.91 & 11.97 & 5.35 & 17.28 \\
\hline EY-7 & 553.00 & 20 & 2.99 & 110.35 & 116.16 & 5.81 & 7.45 & 1.19 & 8.64 \\
\hline EY-8 & 576.00 & 20 & 3.32 & 128.65 & 130.42 & 1.77 & 3.04 & 0.00 & 3.04 \\
\hline EY-9 & 600.00 & 20 & 3.87 & 130.98 & 131.72 & 0.74 & 1.41 & 0.00 & 1.41 \\
\hline EY-10 & 384.20 & 2 & 1.08 & 3.75 & 9.93 & 6.18 & 22.23 & 80.73 & 102.96 \\
\hline$E Y-11$ & 407.40 & 2 & 1.38 & 11.91 & 28.38 & 16.47 & 34.16 & 44.61 & 78.78 \\
\hline EY-12 & 431.90 & 2 & 1.69 & 32.15 & 67.04 & 34.89 & 35.76 & 27.33 & 63.09 \\
\hline$E Y-13$ & 456.00 & 2 & 2.09 & 55.91 & 87.91 & 31.99 & 15.98 & 14.24 & 30.26 \\
\hline EY-14 & 480.70 & 2 & 2.52 & 86.28 & 102.50 & 16.23 & 8.97 & 4.30 & 13.27 \\
\hline EY-15 & 504.50 & 2 & 2.99 & 112.03 & 115.34 & 3.31 & 4.66 & 0.90 & 5.57 \\
\hline EY-16 & 528.50 & 2 & 3.49 & 125.83 & 126.86 & 1.03 & 1.99 & 0.00 & 1.99 \\
\hline EY-17 & 552.40 & 2 & 3.89 & 138.31 & 138.85 & 0.54 & 0.51 & 0.00 & 0.51 \\
\hline EY-18 & 577.50 & 2 & 4.19 & 138.85 & 139.34 & 0.49 & 0.36 & 0.00 & 0.36 \\
\hline EY-19 & 600.00 & 2 & 4.45 & 142.27 & 142.56 & 0.29 & 0.14 & 0.00 & 0.14 \\
\hline
\end{tabular}

and gas generation of Yueguifeng Formation in the West subsag is similar. Under a heating rate of $20^{\circ} \mathrm{C} / \mathrm{h}$ and the temperature of $432^{\circ} \mathrm{C}(R o=1.69)$, the oil reaches the maximum yield and then begins to crack to form natural gas. When the temperature reaches $599.8^{\circ} \mathrm{C}(R o=3.87)$, the maximum yield of natural gas is achieved (Figure 3F).

Under a heating rate of $20^{\circ} \mathrm{C} / \mathrm{h}$, the methane yield of Yueguifeng Formation in the East subsag begins to increase rapidly at $432^{\circ} \mathrm{C}(R o=1.19)$, and the maximum methane yield reaches $130.98 \mathrm{mg} / \mathrm{g}$ TOC when the temperature reaches $600^{\circ} \mathrm{C}$ $(R o=3.87)$. When the temperature reaches $481.2^{\circ} \mathrm{C}(R o=1.81)$, the yield of heavy hydrocarbon gases reaches the maximum value of $42.53 \mathrm{mg} / \mathrm{g}$ TOC. With the increase of temperature, the yield of heavy hydrocarbon gases begins to decrease. When the temperature reaches $600^{\circ} \mathrm{C}(R o=3.87)$, the yield of heavy hydrocarbon gases is close to zero. The maximum yield of heavy hydrocarbon gases is $83.91 \mathrm{mg} / \mathrm{g}$ TOC at $408.1^{\circ} \mathrm{C}(R o=$ 0.96). With the increase of simulation temperature, the yield of heavy hydrocarbon gases decreases gradually. The maximum yield of light oil reaches $30.30 \mathrm{mg} / \mathrm{g}$ TOC at $456^{\circ} \mathrm{C}(R o=1.47)$ and then decreases with the increase of simulated temperature (Figure 3G). Under the heating rate of $2^{\circ} \mathrm{C} / \mathrm{h}$, the methane yield of Yueguifeng Formation in East subsag begins to increase rapidly at $407.4^{\circ} \mathrm{C}(R o=1.38)$, and the maximum methane yield reaches $142.27 \mathrm{mg} / \mathrm{g}$ TOC when the temperature reaches $600^{\circ} \mathrm{C}(R o=$ $4.45)$. When the temperature is $431.9^{\circ} \mathrm{C}(R o=1.69)$, the yield of heavy hydrocarbon gases reaches the maximum value of $34.89 \mathrm{mg} / \mathrm{g}$ TOC, and the yield of heavy hydrocarbon gases gradually decreases with the increase of temperature. The maximum yield of heavy oil components is $80.73 \mathrm{mg} / \mathrm{g}$ TOC at $384.2^{\circ} \mathrm{C}(\mathrm{Ro}=1.08)$, and the maximum yield of light oil components is $35.76 \mathrm{mg} / \mathrm{g}$ TOC at $431.9^{\circ} \mathrm{C} \quad(R o=1.69)$ (Figure 3H). The sample of Yueguifeng Formation in the East subsag generates oil earlier than gas. Under the heating rate of $20^{\circ} \mathrm{C} / \mathrm{h}$ and temperature of $408.1^{\circ} \mathrm{C}(R o=0.96)$, the sample begins to crack to form natural gas. When the temperature reaches $600^{\circ} \mathrm{C}$
$(R o=3.87)$, the natural gas yield reaches the maximum (Figure 3I).

\section{Kinetic Characteristics of Hydrocarbon Generation}

In our gold tube pyrolysis experiment, the hydrocarbon gas yields provide the necessary data for calculating the gas generation kinetics parameters. It is widely accepted that the hydrocarbon generation process of sedimentary organic matter follows the principle of parallel first-order reaction kinetics (Tissot and Welte, 1984; Cramer et al., 2001; Cramer, 2004; Tian et al., 2009; Kotarba and Lewan, 2013; Wang et al., 2014; Wang et al., 2018). Based on this principle, using pyrolysis data and the Lawrence Livermore National Lab Kinetics software, a series of specific kinetic parameters (such as activation energy and frequency factor) are calculated for total hydrocarbon generation (Table 3).

As mentioned above, the source rocks in Lishui Sag are dominated by gas generation, so we focus on the kinetic parameters of natural gas. At different heating rates, the experimental yield of natural gas is in good agreement with the simulation results, which ensures the accuracy of the calculation of kinetic parameters of hydrocarbon generation (Figures 4A,C,E). The activation energy range of natural gas in Lingfeng Formation of the West subsag is $45-65 \mathrm{kcal} / \mathrm{mol}$, the main activation energy is $53 \mathrm{kcal} / \mathrm{mol}$, the average activation energy is $58.37 \mathrm{kcal} / \mathrm{mol}$, and the frequency factor is $9.8 \times 10^{11} \mathrm{~s}^{-1}$ (Figures 4A,B). The activation energy range of natural gas of Yueguifeng Formation in the West subsag is $47-68 \mathrm{kcal} / \mathrm{mol}$, the main activation energy value is $60 \mathrm{kcal} /$ $\mathrm{mol}$, the average activation energy is $57.11 \mathrm{kcal} / \mathrm{mol}$ with frequency factor of $1.2 \times 10^{12} \mathrm{~s}^{-1}$ (Figures 4C,D). The natural gas activation energy of Yueguifeng Formation in the East subsag is $46-64 \mathrm{kcal} / \mathrm{mol}$, the main activation energy is $60 \mathrm{kcal} / \mathrm{mol}$, the average activation energy is $53.31 \mathrm{kcal} / \mathrm{mol}$, and the frequency 
TABLE 3 | Data of kinetic parameters of hydrocarbon generation from source rocks in the Lishui Sag.

\begin{tabular}{|c|c|c|c|c|c|c|c|c|c|c|c|c|c|c|c|c|}
\hline \multicolumn{7}{|c|}{ Lingfeng formation in the west subsag } & \multicolumn{6}{|c|}{ Yueguifeng formation in the west subsag } & \multicolumn{4}{|c|}{ Yueguifeng formation in the east sub sag } \\
\hline Components & $\mathrm{C}_{1}$ & $\mathrm{C}_{2}-\mathrm{C}_{5}$ & $\mathrm{C}_{1}-\mathrm{C}_{5}$ & $\mathrm{C}_{6}-\mathrm{C}_{14}$ & $\mathrm{C}_{14+}$ & $\mathrm{C}_{6+}$ & $\mathrm{C}_{1}$ & $\mathrm{C}_{2}-\mathrm{C}_{5}$ & $\mathrm{C}_{1}-\mathrm{C}_{5}$ & $\mathrm{C}_{6}-\mathrm{C}_{14}$ & $\mathrm{C}_{14+}$ & $\mathrm{C}_{6+}$ & $\mathrm{C}_{1}$ & $\mathrm{C}_{2}-\mathrm{C}_{5}$ & $\mathrm{C}_{1}-\mathrm{C}_{5}$ & $\mathrm{C}_{6}-\mathrm{C}_{14}$ \\
\hline$A\left(S^{-1}\right)$ & $8.5 \times 10^{11}$ & $4.49 \times 10^{13}$ & $9.8 \times 10^{11}$ & $5.03 \times 10^{13}$ & $2.1 \times 10^{13}$ & $4.79 \times 10^{13}$ & $2.2 \times 10^{12}$ & $3.2 \times 10^{13}$ & $1.2 \times 10^{12}$ & $8.8 \times 10^{12}$ & $4.56 \times 10^{13}$ & $8.8 \times 10^{12}$ & $8.9 \times 10^{12}$ & $1.2 \times 10^{13}$ & $6.5 \times 10^{11}$ & $1.5 \times 10^{15}$ \\
\hline $\mathrm{E}(\mathrm{kcal} / \mathrm{mol})$ & \multicolumn{6}{|c|}{ Frequency distribution (\%) } & \multicolumn{6}{|c|}{ Frequency distribution (\%) } & \multicolumn{4}{|c|}{ Frequency distribution (\%) } \\
\hline 41 & 0 & 0 & 0 & 0 & 0 & 0 & 0 & 0 & 0 & 4.99 & 0 & 3.42 & 0 & 0 & 0 & 0 \\
\hline 42 & 0 & 0 & 0 & 0 & 28.69 & 0 & 0 & 0 & 0 & 0 & 0.34 & 0 & 0 & 0 & 0 & 0 \\
\hline 43 & 0 & 0 & 0 & 0 & 1.27 & 11.52 & 0 & 0 & 0 & 0 & 0 & 0 & 0 & 0.02 & 0 & 0 \\
\hline 44 & 0 & 0 & 0 & 0 & 0 & 0 & 0.01 & 0 & 0 & 0 & 0.22 & 0.28 & 0 & 0 & 0 & 0 \\
\hline 45 & 0 & 0 & 0.11 & 0 & 0 & 0 & 0 & 0 & 0 & 0.42 & 0 & 1.25 & 0 & 0.21 & 0 & 0 \\
\hline 46 & 0.04 & 0 & 0.53 & 0.11 & 2.47 & 2.63 & 0 & 0 & 0 & 0 & 0 & 0 & 0 & 0 & 0.44 & 0 \\
\hline 47 & 0.21 & 0 & 0 & 0 & 8.32 & 0 & 0 & 0.17 & 0.64 & 0 & 3.29 & 0 & 0.51 & 0 & 0 & 0 \\
\hline 48 & 0 & 0 & 0.25 & 1.84 & 0 & 0 & 0.25 & 0 & 0.6 & 0 & 0 & 0 & 0.09 & 1.64 & 0 & 0 \\
\hline 49 & 0 & 0 & 0 & 0 & 3.36 & 6.11 & 0.63 & 0 & 0 & 8.88 & 0 & 8.06 & 0 & 3.46 & 0 & 0 \\
\hline 50 & 0 & 0.91 & 0 & 0 & 4.13 & 7.64 & 0 & 0 & 0 & 0 & 0 & 0 & 0 & 0 & 0 & 0 \\
\hline 51 & 0 & 0 & 0 & 0 & 3.73 & 3.67 & 0 & 0.26 & 0 & 37.6 & 0 & 10.13 & 0 & 0 & 0 & 25.03 \\
\hline 52 & 2.05 & 4.41 & 2.58 & 3.41 & 0 & 19.3 & 0 & 0 & 5.25 & 0 & 0 & 62.53 & 0 & 0 & 27.17 & 2.09 \\
\hline 53 & 15.81 & 0 & 19.32 & 8.51 & 13.59 & 1.7 & 1.71 & 20.76 & 22.44 & 15.98 & 0 & 0 & 25.15 & 62.85 & 13.03 & 0 \\
\hline 54 & 0 & 0 & 0 & 8.44 & 4.17 & 4.57 & 23.66 & 0 & 0 & 14.93 & 73.61 & 0 & 0 & 20.9 & 0 & 0 \\
\hline 55 & 0 & 0 & 0 & 25.97 & 13.82 & 30.36 & 0 & 0 & 0 & 0 & 0 & 11.04 & 3.16 & 0 & 13.94 & 0 \\
\hline 56 & 27.45 & 62.35 & 14.26 & 0 & 2.4 & 0 & 0 & 62.1 & 26.29 & 14.81 & 14.49 & 3.3 & 25.1 & 9.46 & 9.83 & 12.01 \\
\hline 57 & 0 & 0 & 11.78 & 0 & 14.07 & 10.35 & 30.34 & 4.02 & 4.12 & 1.37 & 6.73 & 0 & 0 & 1.45 & 0.71 & 0 \\
\hline 58 & 0 & 20.27 & 0 & 43.19 & 0 & 2.14 & 2.97 & 10.27 & 0 & 1.03 & 0 & 0 & 20.53 & 0 & 11.73 & 0 \\
\hline 59 & 10.96 & 11.01 & 0 & 0 & 0 & 0 & 0 & 0 & 0 & 0 & 1.33 & 0 & 0 & 0 & 0 & 0 \\
\hline 60 & 21.62 & 0 & 26.27 & 0 & 0 & 0 & 0 & 2.42 & 30.87 & 0 & 0 & 0 & 10.64 & 0 & 19.43 & 52.32 \\
\hline 61 & 0 & 0 & 4.96 & 4.2 & 0 & 0 & 31.14 & 0 & 0 & 0 & 0 & 0 & 8.68 & 0 & 0 & 0 \\
\hline 62 & 0 & 0.49 & 0 & 4.33 & 0 & 0 & 0 & 0 & 0.78 & 0 & 0 & 0 & 0 & 0 & 0 & 0 \\
\hline 63 & 0 & 0.55 & 0 & 0 & 0 & 0 & 0 & 0 & 0 & 0 & 0 & 0 & 0 & 0 & 0 & 3.11 \\
\hline 64 & 11.72 & 0 & 5.85 & 0 & 0 & 0 & 0.86 & 0 & 7.57 & 0 & 0 & 0 & 6.15 & 0 & 3.73 & 5.44 \\
\hline 65 & 10.13 & 0 & 14.08 & 0 & 0 & 0 & 6.44 & 0 & 0 & 0 & 0 & 0 & 0 & 0 & 0 & 0 \\
\hline 66 & 0 & 0 & 0 & 0 & 0 & 0 & 0 & 0 & 0 & 0 & 0 & 0 & 0 & 0 & 0 & 0 \\
\hline 67 & 0 & 0 & 0 & 0 & 0 & 0 & 0 & 0 & 0 & 0 & 0 & 0 & 0 & 0 & 0 & 0 \\
\hline 68 & 0 & 0 & 0 & 0 & 0 & 0 & 2.01 & 0 & 1.43 & 0 & 0 & 0 & 0 & 0 & 0 & 0 \\
\hline 69 & 0 & 0 & 0 & 0 & 0 & 0 & 0 & 0 & 0 & 0 & 0 & 0 & 2.18 & 0 & 0 & 0.57 \\
\hline
\end{tabular}

factor is $6.5 \times 10^{11} \mathrm{~s}^{-1}$ (Figures 4E,F). The frequency factor (A) refers to the factor of the total number of effective collisions of activated molecules, and the larger the value is, the easier the chemical reaction will be (Galwey and Brown, 2002; He et al., 2020).

\section{DISCUSSION}

\section{Difference Analysis of Hydrocarbon Generation Characteristics}

Under different heating rates, the maximum yield of hydrocarbon generation products of the selected samples in Lishui Sag is stable (Figure 3), indicating that, in geological history, the hydrocarbon generation potential of source rocks depends on the composition and structure of kerogen and has little to do with sedimentation rate and geothermal gradient. The oil components yield of the Yueguifeng and Lingfeng Formations in the West subsag is low, and, with the increase of simulation temperature, the maximum yield almost simultaneously begins to decrease, indicating that the source rocks of the West subsag are typical gas-prone source rocks. According to the principle of conservation of mass, the methane generated by the source rocks of the West subsag should be mainly generated by direct cracking of kerogen, and the proportion of methane converted from oil components is relatively small. Although the degree of thermal evolution of the source rock in Yueguifeng Formation is relatively high, the distribution characteristics of its oil yield first increased and then decreased, which indicates the source rocks of Yueguifeng Formation are still in the main hydrocarbon generation period. The maximum yield of natural gas of Lingfeng
Formation in the West subsag is higher than that of Yueguifeng Formation, which indicates that the gas generation potential of Lingfeng formation source rock is higher than that of Yueguifeng Formation. The hydrocarbon generation characteristics of the Yueguifeng Formation source rocks in the East subsag are quite different from those in the West subsag. Firstly, the yield of source rock of Yueguifeng Formation in the East subsag is much higher than that in the West subsag. It is worth noting that the sample of Yueguifeng Formation in the East subsag has relative high oil potential. The simulation results show that, at the temperature which is equivalent to the current maturity, the oil component has reached the maximum yield. Due to its high thermal evolution, it may be in the stage of oil generation peak or after the oil generation peak. At the heating rate of $20^{\circ} \mathrm{C} / \mathrm{h}$, when the simulated temperature is lower than $456^{\circ} \mathrm{C}(R o=1.47)$, the yield of heavy oil components decreases, while the yield of light oil components increases, and the yield of overall oil component also decreases. It shows that, with the increase of simulation temperature, heavy oil components will crack to form light oil components and natural gas (Figures 3G,I). In the case of similar thermal evolution degree, the hydrocarbon generation potential of Yueguifeng Formation in the East subsag is much higher than that in the West subsag, which may be related to the composition of organic matter.

In this study, the distribution characteristics of activation energy of methane and oil components are selected to analyze the difference of hydrocarbon generation kinetics of source rocks in the Lishui Sag. The range of activation energy for methane of the Lingfeng Formation in the West subsag is $46-65 \mathrm{kcal} / \mathrm{mol}$, and the main activation energy value is $56 \mathrm{kcal} / \mathrm{mol}$. The range of 

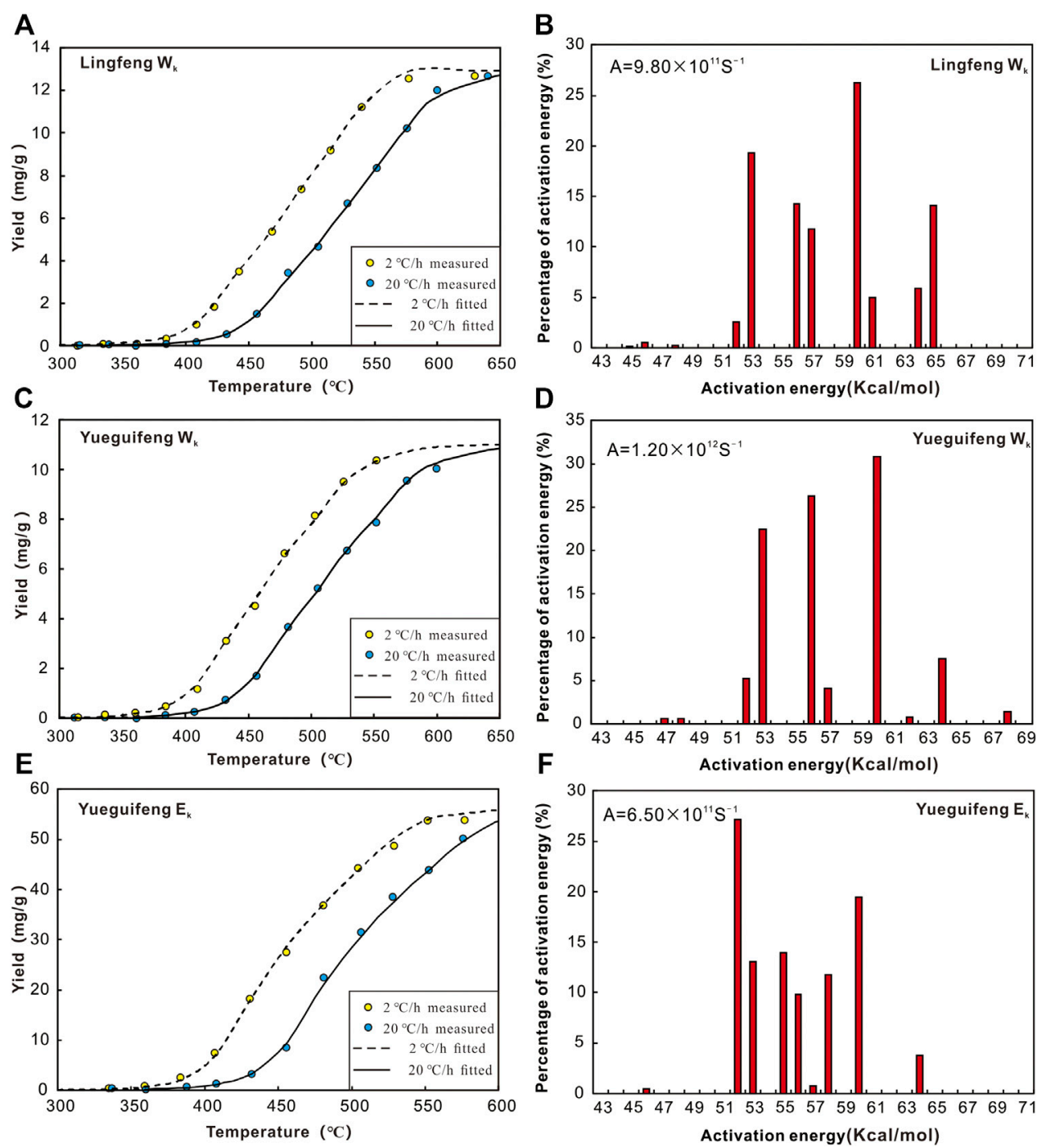

FIGURE 4 | Fitting results of natural gas yield and distribution of activation energy for hydrocarbon generation of the source rocks in the Lishui Sag. A = frequency factor.

activation energy for methane of the Yueguifeng Formation in the West subsag is $44-68 \mathrm{kcal} / \mathrm{mol}$, and the main activation energy value is $61 \mathrm{kcal} / \mathrm{mol}$. The activation energy range of methane for the sample of the Yueguifeng Formation in the East subsag is $47-69 \mathrm{kcal} / \mathrm{mol}$, and the main activation energy value is $53 \mathrm{kcal} /$ mol (Figure 5A). According to the distribution of activation energy for methane, when the average activation energy difference is small, the distribution range of methane activation energy of Lingfeng Formation in the West subsag is the narrowest, which indicates that it is easier to generate methane. On the whole, there is little difference in the kinetic characteristics of methane generation in Lishui Sag. The range of activation energy for oil components in Lingfeng Formation of the West subsag is $43-58 \mathrm{kcal} / \mathrm{mol}$, and the main activation energy value is $55 \mathrm{kcal} / \mathrm{mol}$. The range of activation energy for oil components in Yueguifeng Formation in the West subsag is $41-56 \mathrm{kcal} / \mathrm{mol}$, and the main activation energy value is $52 \mathrm{kcal} / \mathrm{mol}$. And the range of activation energy for oil components in Yueguifeng
Formation in the East subsag is $31-47 \mathrm{kcal} / \mathrm{mol}$ with a main activation energy value of $41 \mathrm{kcal} / \mathrm{mol}$ (Figure 5B). Obviously, the hydrocarbon generation kinetic characteristics of the samples of Lingfeng and Yueguifeng Formations in the West subsag are similar, while the samples of Yueguifeng Formation in the East subsag show its particularity with lower distribution range and average activation energy, and its oil generating capacity and potential are much higher than those of source rocks in the West subsag.

\section{Macerals of Kerogen Control the Model of Hydrocarbon Generation}

Li et al. (2019) indicate that the mudstone of Yueguifeng Formation shows high maturity and the advantage of aquatic organic matter input. The organic matter input heterogeneity of Lingfeng Formation mudstone is high, aquatic input is dominant 

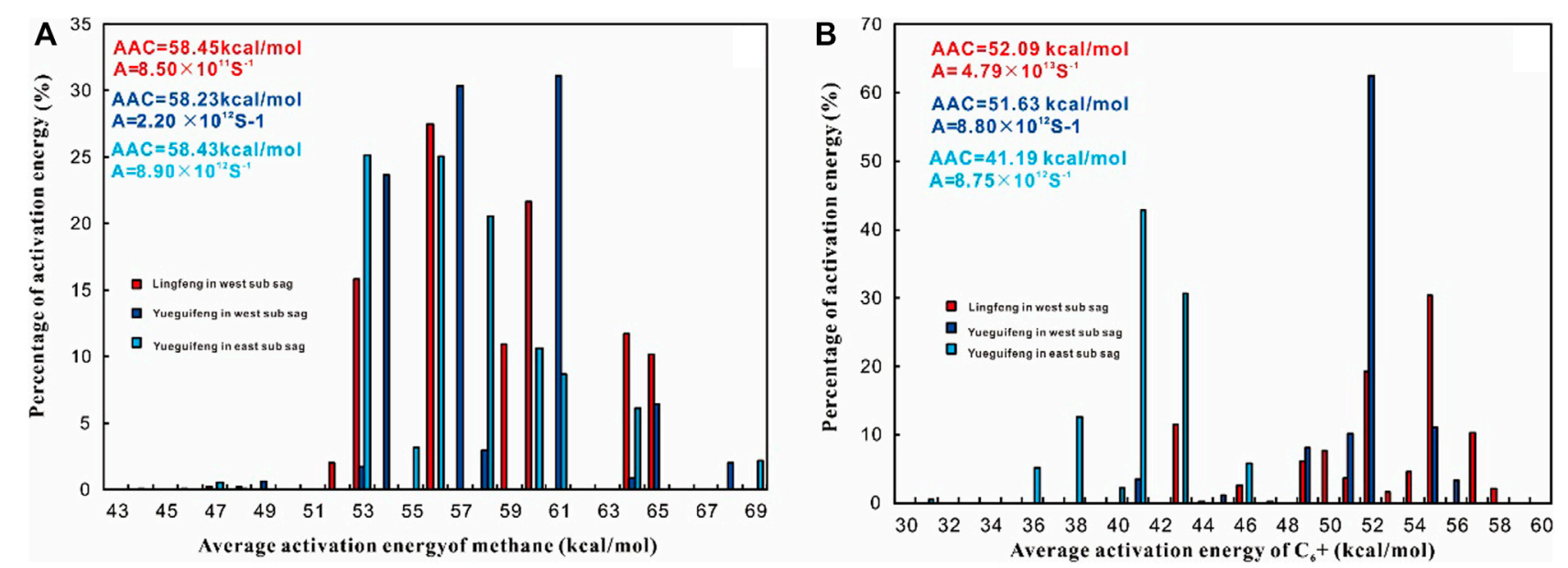

FIGURE 5 | Distribution of activation energy for hydrocarbon generation of methane and oil components AAC: average activation energy

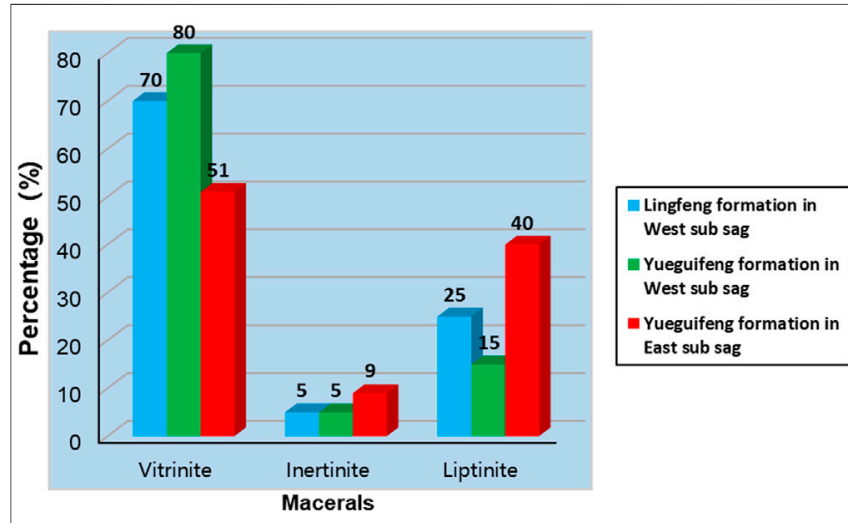

FIGURE 6 | Maceral composition of selected samples in the Lishui Sag.

in the lower part, and terrigenous input is dominant in the upper part. The mudstone of Yueguifeng Formation was deposited in saline lake with high clay content and relatively high salinity, while the mudstone of Lingfeng Formation was deposited in the transitional sedimentary environment. Generally, the source rocks in Lishui Sag show the characteristics of mixed organic matter input and the evolution process of sedimentary environment from continental facies to marine facies. The instability of organic matter input and the transitional sedimentary environment may be the main reasons for the dominance of type III kerogen of source rocks in Lishui Sag. As mentioned above, although the kerogen types of the source rocks in Lishui Sag are consistent in terms of pyrolysis parameters, their hydrocarbon generation characteristics are quite different. Therefore, it is not rigorous to judge the hydrocarbon generation potential of source rocks only from the types of kerogen derived from pyrolysis parameters. In this study, the maceral analysis of the selected samples was carried out in order to analyze the causes of the differences in hydrocarbon generation characteristics of the source rocks in Lishui Sag.

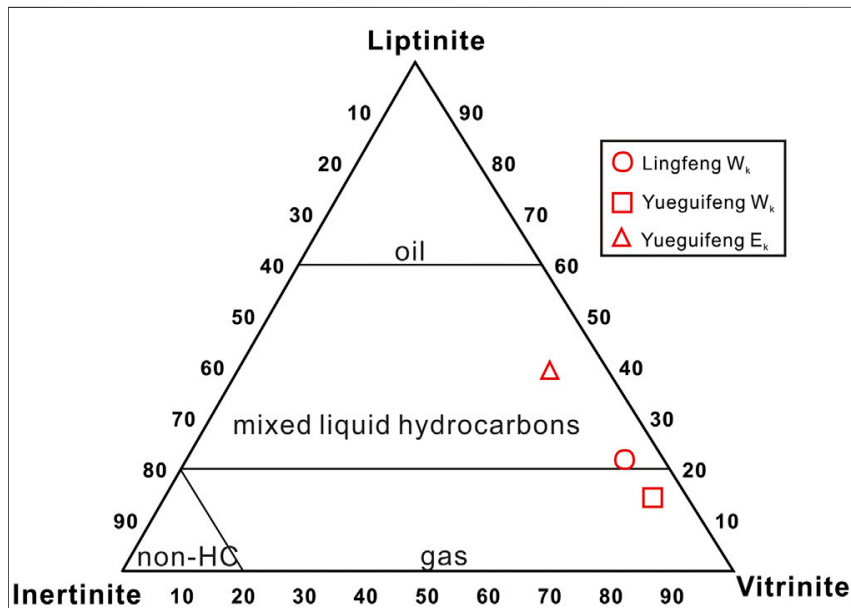

FIGURE 7 | Ternary plots of the maceral composition, showing anticipated hydrocarbon phase of the selected samples in the Lishui Sag (modified after Tissot and Welte, 1984).

As shown in Figure 6, the maceral composition of source rocks in the West subsag and the East subsag is dominated by vitrinite. The vitrinite content of Lingfeng Formation and Yueguifeng Formation in the West subsag is dominant $(\geq 70 \%)$, while the vitrinite content of Yueguifeng Formation in the East subsag is much lower than that in the West subsag. The content of liptinite in source rocks of Yueguifeng Formation in the East subsag is second only to vitrinite and much higher than that in the West subsag. There is a consensus that vitrinite is the main gas dipping macerals, and liptinite is the main oil dipping macerals (Tissot and Welte, 1984; Peters et al., 2005; Hakimi and Ahmed, 2016). According to the maceral composition, the source rocks in Lishui Sag are dominated by gas generation, and the source rocks of Yueguifeng Formation in the East subsag also have certain oil generation potential (Figure 7). 


\section{Classification of Kerogen Types From Mixed Organic Matter Sources}

Through the hydrocarbon generation simulation experiment and maceral analysis of source rocks in the Lishui Sag, a limitation in inference of the hydrocarbon generation potential of source rocks is highlighted when only based on the types of kerogen obtained by pyrolysis parameters, especially for the source rocks with mixed organic matter sources. According to the classification of kerogen types in source rocks, many schemes have been proposed (Tissot and Welte, 1984; Van Krevelen, 1993). The results of previous studies show that the combination of kerogen type index (KTI $=\mathrm{S}_{2} / \mathrm{S}_{3}=\mathrm{HI} /$ $\mathrm{OI})$ can more effectively distinguish the boundary of kerogen types, especially for the mixed region division of type II and type III kerogen (Huang et al., 1982; Huang et al., 1984; Peters et al., 2005). However, it should be noted that, due to the differences in the research objects of scholars, there is no consensus on the value limit of KTI in the classification of kerogen types. Peters et al. (2005) classified kerogen into five types according to pyrolysis parameters and $S_{2} / S_{3}$ values. The values of $S_{2} / S_{3}$ for different types of kerogen are type IV $<1,1 \leq$ type III $<5,5 \leq$ type II/III $<10,10 \leq$ type II $<15$, type I $\geq 15$ (Peters et al., 2005). According to the pyrolysis parameters of hydrogen index (HI), oxygen index (OI), and their ratios, Huang et al. (1982) established an X-type diagram for the classification of kerogen types and divided kerogen into five types. With the improvement of the data and the deepening of the research, the value limits of $\mathrm{HI} / \mathrm{OI}$ are adjusted: type $\mathrm{III}_{2}<0.5,0.5 \leq$ type $\mathrm{III}_{1}<$ $1.5,1.5 \leq$ type $\mathrm{II}<15,1.5 \leq$ type $\mathrm{I}_{2}<40$,type $\mathrm{I}_{1} \geq 40$ (Huang et al., 1984). In this study, based on the hydrogen index, the types of kerogen should be typical type III, but its hydrocarbon generation characteristics are quite different. Therefore, the kerogen type should be redefined according to the hydrocarbon generation characteristics of the source rocks in Lishui Sag. Based on the hydrocarbon generation characteristics of the source rocks derived from mixed organic matter in the Lishui Sag, a new value limit of kerogen type index is proposed to classify kerogen types. Type IV kerogen (KTI < 0.5) has low hydrocarbon generation capacity, and "dead carbon" occurs when hydrogen index is lower than $50 \mathrm{mg} / \mathrm{g}$; type III kerogen $(0.5 \leq \mathrm{KTI}<1.5)$ mainly produces gas, and, with the increase of KTI value, a small amount of liquid hydrocarbon may be produced; type II/III kerogen $(1.5 \leq \mathrm{KTI}<5)$ mainly produces gas, but its oil generation capacity is much higher than that of type III kerogen; type II kerogen $(5 \leq \mathrm{KTI}<15)$ and type I kerogen $(\mathrm{KTI}>15)$ are mainly oil prone (Figure 8). According to the dynamic characteristics of the selected kerogen, the main activation energy for methane of type II/III kerogen is less than that of type III kerogen, and the range of activation energy is similar. However, the main activation energy for oil components of type II/III kerogen is significantly smaller than that in type III kerogen, and the range of activation energy is also smaller than that of type III kerogen (Figure 5). The above phenomena indicate that the kinetic characteristics of gas generation between type II/III kerogen and type III kerogen are similar, but type II/III kerogen is easier to generate oil.

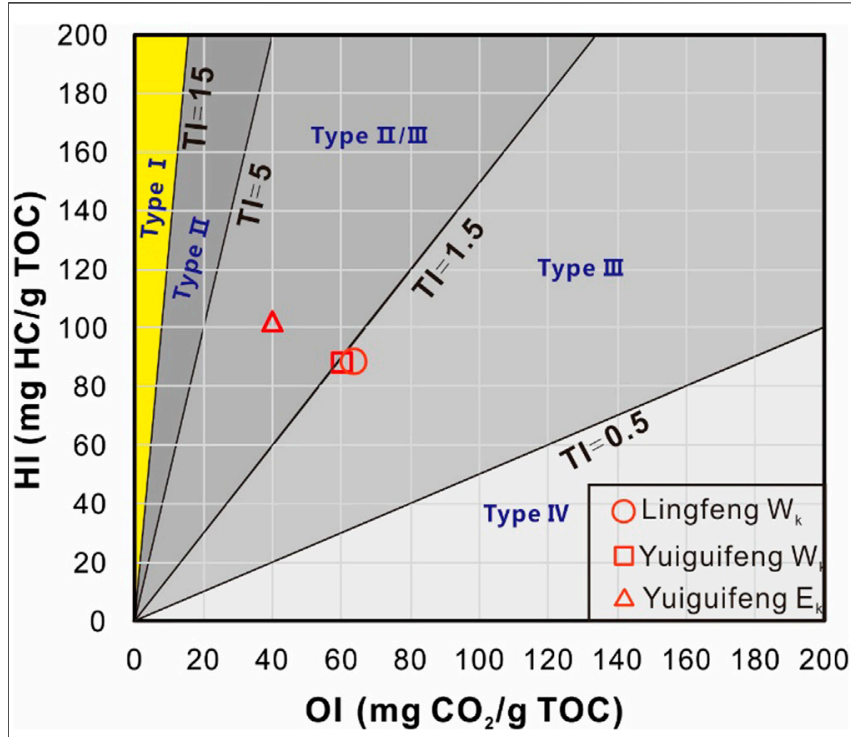

FIGURE 8 | Classification chart of kerogen types (modified after Van Krevelen, 1993; Peters et al., 2005).

\section{CONCLUSION}

According to the characteristics of pyrolysis hydrogen index and oxygen index, the kerogen type of source rocks in Lishui Sag is mainly type III kerogen. Due to deep burial, the source rocks in Lishui Sag are basically in mature stage. The simulation of hydrocarbon generation by gold tube pyrolysis experiment shows that the source rocks in Lishui Sag mainly generate natural gas, and the hydrocarbon generation characteristics of source rocks in different structural positions are quite different. The oil yield of type III kerogen in Lingfeng and Yueguifeng Formations in the West subsag is relatively low. The natural gas is dominantly methane, which is mainly produced by direct cracking of kerogen. Based on the maximum yield and kinetic characteristics of hydrocarbon generation, the hydrocarbon potential of Lingfeng Formation in the West subsag is higher than that in Yueguifeng Formation. The hydrocarbon potential of Yueguifeng Formation source rock in the East subsag is much higher than that in the West subsag, and it has considerable oil potential.

Maceral analysis shows that the content of liptinite of the Yueguifeng Formation in the East subsag is much higher than that of the West subsag, which may responsible for the difference of hydrocarbon generation characteristics. For source rocks with mixed sources of organic matter, it is not rigorous to judge the type of kerogen only by hydrogen index and oxygen index, and maceral analysis should be supplemented to comprehensively judge hydrocarbon potential. Comprehensive use of kerogen type index (KTI), pyrolysis hydrogen index, and oxygen index can improve the accuracy of kerogen type classification of source rocks with mixed organic matter sources. We subdivided the mainly gas producing kerogen with mixed organic matter source into type III and 
type II/III. Type III kerogen $(0.5 \leq \mathrm{KTI}<1.5)$ mainly produces gas and, with the increase of KTI value, a small amount of liquid hydrocarbon may be produced. Type II/III kerogen $(1.5 \leq \mathrm{KTI}$ $<5)$ mainly produces gas, but its oil production capacity is much higher than that of type III kerogen.

In this study, the hydrocarbon generation model of type III kerogen with different maturity and structural position in Lishui Sag was investigated by the gold tube hydrocarbon generation simulation experiment in a closed system, and its hydrocarbon generation potential was evaluated, so as to provide theoretical basis for oil and gas exploration in Lishui Sag at the early stage of exploration. Based on the gold tube pyrolysis experiment, it is found that the hydrocarbon generation modes of type III kerogen divided by traditional pyrolysis parameters are quite different, which emphasizes the importance of maceral analysis in oil and gas potential evaluation. The next exploration direction of Lishui Sag should be in the East subsag, mainly for oil and gas, and the West subsag should be mainly for gas traps.

\section{REFERENCES}

Agrawal, V., and Sharma, S. (2020). Are we modeling the properties of unconventional shales correctly. Fuel 267, 1-7. doi:10.1016/j.fuel.2020.117316

Bayon, R. L., Brey, G. P., Ernst, W. G., and Mählmann, R. F. (2011). Experimental kinetic study of organic matter maturation: time and pressure effects on vitrinite reflectance at $400^{\circ} \mathrm{C}$. Org. Geochem. 42, 340-355. doi:10.1016/j. orggeochem.2011.01.011

Behar, F., Vandenbroucke, M., Teerman, S. C., Hatcher, P. G., Leblond, C., and Lerat, O. (1995). Experimental simulation of gas generation from coals and a marine kerogen. Chem. Geol. 126, 247-260. doi:10.1016/0009-2541(95)00121-2

Chen, J. P., Ge, H. P., Chen, X. D., Deng, C. P., and Liang, D. J. (2008). Classification and origin of natural gases from Lishui Sag, the east China Sea basin. Sci. China Earth Sci. 51, 122-130. doi:10.1007/s11430-008-5001-5

Cheng, X., Hou, D., Zhao, Z., Chen, X., and Diao, H. (2019). Sources of natural gases in the Xihu Sag, east China Sea basin: insights from stable carbon isotopes and confined system pyrolysis. Energy Fuels 33, 2166-2175. doi:10.1021/acs. energyfuels.9b00090

Cramer, B., Faber, E., Gerling, P., and Krooss, B. M. (2001). Reaction kinetics of stable carbon isotopes in natural gassinsights from dry, open system pyrolysis experiments. Energy Fuels 15, 517-532. doi:10.1021/ef000086h

Cramer, B. (2004). Methane generation from coal during open system pyrolysis investigated by isotope specific Gaussian distributed reaction kinetics. Org. Geochem. 35, 379-392. doi:10.1016/j.orggeochem.2004.01.004

Dembicki, H. (2009). Three common source rock evaluation errors made by geologists during prospect or play appraisals. AAPG Bull. 93, 341-356. doi:10. $1306 / 10230808076$

Dieckmann, V., Schenk, H. J., and Horsfield, B. (2000). Assessing the overlap of primary and secondary reactions by closed- versus open-system pyrolysis of marine kerogens. J. Anal. Appl. Pyrol. 56, 33-46. doi:10.1016/S0165-2370(00)00083-8

Dieckmann, V., Schenk, H. J., Horsfield, B., and Welte, D. H. (1998). Kinetics of petroleum generation and cracking by programmed-temperature closedsystem pyrolysis of Toarcian Shales. Fuel 77, 23-31. doi:10.1016/S00162361(97)00165-8

Galwey, A. K., and Brown, M. E. (2002). Application of the Arrhenius equation to solid state kinetics: can this be justified?. Thermochim. Acta. 386 (1), 91-98. doi:10.1016/S0040-6031(01)00769-9

Ge, H., Chen, J., Chen, X., Deng, C. P., and Liang, D. (2007). Discussion on the type and origin of natural gas in Lishui Sag of the East China Sea basin. Sci. China Earth Sci. 51, 104-110. doi:10.1007/s11430-008-5001-5

Hakimi, M. H., and Ahmed, A. F. (2016). Petroleum source rock characterisation and hydrocarbon generation modeling of the Cretaceous sediments in the Jiza sub-basin, eastern Yemen. Mar. Petrol. Geol. 75, 356-373. doi:10.1016/j. marpetgeo.2016.04.008

\section{DATA AVAILABILITY STATEMENT}

The original contributions presented in the study are included in the article/supplementary materials; further inquiries can be directed to the corresponding author.

\section{AUTHOR CONTRIBUTIONS}

JZ participated in conceptualization. YL carried out conceptualization, methodology, writing original draft, and validation and software. JL, LL, WS, and XY performed data curation and used software.

\section{FUNDING}

This article was supported by the Major National R\&D Projects of China (No. 2016ZX05027-001-006).

Hartwig, A., Primio, R. D., Anka, Z., and Horsfield, B. (2012). Source rock characteristics and compositional kinetic models of Cretaceous organic rich black shales offshore southwestern Africa. Org. Geochem. 51, 17-34. doi:10. 1016/j.orggeochem.2012.07.008

He, L., Ma, Y., Yue, C. T., Wu, J., and Li, S. (2020). Kinetic modeling of Kukersite oil shale pyrolysis with thermal bitumen as an intermediate. Fuel 279, 118371. doi:10.1016/j.fuel.2020.118371

Hill, R. J., Tang, Y. C., and Kaplan, I. R. (2003). Insights into oil cracking based on laboratory experiments. Org. Geochem. 34, 1651-1672. doi:10.1016/S01466380(03)00173-6

Hill, R. J., Zhang, E., Katz, B. J., and Tang, Y. (2007). Modeling of gas generation from the Barnett Shale, Fort Worth Basin, Texas. AAPG (Am. Assoc. Pet. Geol.) Bull. 91, 501-521. doi:10.1306/12060606063

Horsfield, B. (1989). Practical criteria for classifying kerogens: some observations from pyrolysis-gas chromatography. Geochem. Cosmochim. Acta. 53, 891-901. doi:10.1016/0016-7037(89)90033-1

Huang, D., and Li, J. (1982). Diagram of kerogen classification and the characters of kerogen of standard humic type. Geochimica 1, 21-30 [in Chinese]. doi:10. 19700/j.0379-1726.1982.01.003

Huang, D., Li, J., and Zhang, D. (1984). Kerogen types and study on effectiveness, limitation and interrelation of their identification parameters. Acta Sedimentol. Sin. 3, 18-33+135 [in Chinese]. doi:10.14027/j.cnki.cjxb.1984.03.002

Jasper, K., Krooss, B. M., Flajs, G., Hartkopf-Fröder, C., and Littke, R. (2009). Characteristics of type III kerogen in coal-bearing strata from the Pennsylvanian (Upper Carboniferous) in the Ruhr Basin, Western Germany: comparison of coals, dispersed organic matter, kerogen concentrates and coal-mineral mixtures. Int. J. Coal Geol. 80, 1-19. doi:10.1016/j.coal.2009.07.003

Kotarba, M. J., and Lewan, M. D. (2013). Sources of natural gases in Middle Cambrian reservoirs in Polish and Lithuanian Baltic Basin as determined by stable isotopes and hydrous pyrolysis of Lower Palaeozoic source rocks. Chem. Geol. 345, 62-76. doi:10.1016/j.chemgeo.2013.02.023

Lewan, M. D., and Roy, S. (2011). Role of water in hydrocarbon generation from Type-I kerogen in Mahogany oil shale of the Green River Formation. Org. Geochem. 42, 31-41. doi:10.1016/j.orggeochem.2010.10.004

Li, D. Y., Jiang, X. D., Xu, F., Liu, J., and Hou, G. (2016). Geochemistry of the Paleocene in Lishui Sag, East China Sea Shelf basin: implications for tectonic background and provenance. Acta Geol. Sin.-Engl. Ed. 90, 166-181. doi:10. 1111/1755-6724.12649

Li, J., Ma, W., Wang, Y., Wang, D., Xie, Z., Li, Z., et al. (2018). Modeling of the whole hydrocarbon-generating process of sapropelic source rock. Petrol. Explor. Dev. 45, 445-454. doi:10.1016/S1876-3804(18)30051-X

Li, N., Zhang, J., Shen, W., Liu, Y., Liu, H., Wang, J., et al. (2020). Recovery of the erosion thickness and characterization of the paleogeomorphology in the southern Lishui Sag, East China Sea Shelf basin. J. Ocean Univ. China 19, 320-330. doi:10.1007/s11802-020-3957-8 
Li, Y., Zhang, J., Liu, Y., Shen, W., Chang, X., Sun, Z., et al. (2019). Organic geochemistry, distribution and hydrocarbon potential of source rocks in the Paleocene, Lishui sag, East China Sea Shelf basin. Mar. Petrol. Geol. 107, 382-396. doi:10.1016/j.marpetgeo.2019.05.025

Liu, L., Li, Y., Dong, H., and Sun, Z. (2020). Diagenesis and reservoir quality of Paleocene tight sandstones, Lishui Sag, East China Sea Shelf basin. J. Petrol. Sci. Eng. 195, 107615. doi:10.1016/j.petrol.2020.107615

Liu, W. H., Wang, J., TengerQin, J. Z., and Zheng, L. J. (2012). Stable carbon isotopes of gaseous alkanes as genetic indicators inferred from laboratory pyrolysis experiments of various marine hydrocarbon source materials from southern China. Sci. China Earth Sci. 55, 966-974. doi:10.1007/s11430-012-4392-5

Peters, K. E., Walters, C. C., and Moldowan, J. M. (2005). The biomarker guide: biomarkers and isotopes in petroleum exploration and earth history. 2nd Edn. Cambridge, United Kingdom: Cambridge University Press, 75-76

Ruble, T. E., Lewan, M. D., and Philp, R. P. (2001). New insights on the green river petroleum system in the uinta basin from hydrous pyrolysis experiments. AAPG (Am. Assoc. Pet. Geol.) Bull. 85, 1333-1371. doi:10.1306/8626CAB9173B-11D7-8645000102C1865D

Ruble, T. E., Lewan, M. D., and Philp, R. P. (2003). New insights on the Green River petroleum system in the Uinta basin from hydrous-pyrolysis experiments: reply. AAPG (Am. Assoc. Pet. Geol.) Bull. 87, 1535-1541. doi:10.1306/ $0423030137 \mathrm{r}$

Seewald, J. S. (2003). Organic-inorganic interactions in petroleum-producing sedimentary basins. Nature 426, 327-333. doi:10.1038/nature02132

Shen, W., Qi, B., and Xu, G. (2019). The seismic inversion based organic matter abundance predictionmethod for source rocks and its application in Lishui Sag. China Offshore Oil Gas. 31, 68-74 [in Chinese]. doi:10.11935/j.issn.1673-1506. 2019.03.008

Su, A., Chen, H. H., Cao, L. S., Lei, M., Wang, C., Liu, Y., et al. (2014). Genesis, source and charging of oil and gas in Lishui sag, East China Sea basin. Petrol. Explor. Dev. 41, 574-584. doi:10.1016/S1876-3804(14)60068-9

Su, A., Chen, H. H., Wang, C. W., Li, P., Zhang, H., Xiong, W., et al. (2013). Genesis and maturity identification of oil and gas in the Xihu sag, East China Sea basin. Petrol. Explor. Dev. 40, 558-565. doi:10.1016/S1876-3804(13)60073-7

Sun, Z., Zhang, J., Liu, Y., Shen, W., Li, Y., and Li, L. (2020). Sedimentological signatures and identification of Paleocene sedimentary facies in the Lishui Sag, East China Sea Shelf basin. Can. J. Earth Sci. 57, 377-395. doi:10.1139/cjes-2019-0022

Tang, Y., Jenden, P. D., Nigrini, A., and Teerman, S. C. (1996). Modeling early methane generation in coal. Energy Fuels 10, 659-671. doi:10.1021/ef9501531

Tian, H., Xiao, X., Wilkins, R. W., and Tang, Y. (2012). An experimental comparison of gas generation from three oil fractions: implications for the chemical and stable carbon isotopic signatures of oil cracking gas. Org. Geochem. 46, 96-112. doi:10.1016/j.orggeochem.2012.01.013

Tian, H., Xiao, X., Yang, L., Xiao, Z., Guo, L., Shen, J., et al. (2009). Pyrolysis of oil at high temperatures: gas potentials, chemical and carbon isotopic signatures. Chin. Sci. Bull. 54, 1217-1224. doi:10.1007/s11434-008-0590-0
Tissot, B. P. (1984). Recent advances in petroleum geochemistry applied to hydrocarbon exploration. AAPG Bull. 68, 546-563. doi:10.1306/AD46133616F7-11D7-8645000102C1865D

Tissot, B. P., and Welte, D. H. (1984). Petroleum formation and occurrence. New York, NY: Springer-Verlag

Van Krevelen, D. W. (1993). Coal: typology, physics, chemistry, constitution. Amsterdam, Netherlands: Elsevier, 979

Wang, M., Lu, S. F., and Xue, H. T. (2011). Kinetic simulation of hydrocarbon generation from lacustrine type I kerogen from the Songliao Basin: model comparison and geological application. Mar. Petrol. Geol. 28, 1714-1726. doi:10.1016/j.marpetgeo.2011.07.004

Wang, Q., Zou, H., Hao, F., Zhu, Y., Zhou, X., Wang, Y., et al. (2014). Modeling hydrocarbon generation from the Paleogene source rocks in Liaodong Bay, Bohai Sea: a study on gas potential of oil-prone source rocks. Org. Geochem. 76, 204-219. doi:10.1016/j.orggeochem.2014.08.007

Wang, Y., Zou, Y., Zhan, Z., Lin, X.-H., and Liang, T. (2018). Origin of natural gas in the Turpan-Hami Basin, NW China: evidence from pyrolytic simulation experiment. Int. J. Coal Geol. 195, 238-249. doi:10.1016/j.coal.2018.06.007

Xu, C., Ye, J., Liu, J., Caoa, Q., Sheng, Y., and Yu, H. (2020). Simulation of hydrocarbon generation and expulsion for the dark mudstone with type-III kerogen of Pinghu Formation in Xihu Sag, East China Sea Basin under near geological conditions. Oil Gas Geol. 41, 359-366 [in Chinese]. doi:10.11743/ ogg20200212

Zhang, E., Hill, R. J., Katz, B. J., and Tang, Y. (2008). Modeling of gas generation from the Cameo coal zone in the Piceance Basin, Colorado. American AAPG Bulletin 92, 1077-1106. doi:10.1306/04020806015

Zhang, J., Guo, J., Liu, J., and Shen, W. (2019). 3D-Basin modelling of the Lishui Sag: research of hydrocarbon potential, petroleum generation and migration. Energies 12 (4), 650. doi:10.3390/en12040650

Zhang, M., Zhang, J. L., Xu, F., Li, J., Liu, J., Hou, G., et al. (2015). Paleocene sequence stratigraphy and depositional systems in the Lishui Sag, East China Sea Shelf Basin. Mar. Petrol. Geol. 59, 390-405. doi:10.1016/j.marpetgeo.2014.09.015

Conflict of Interest: Authors JL and WS are employed by CNOOC China Ltd.

The remaining authors declare that the research was conducted in the absence of any commercial or financial relationships that could be construed as a potential conflict of interest.

Copyright $\odot 2021$ Zhang, Li, Liu, Yan, Li and Shen. This is an open-access article distributed under the terms of the Creative Commons Attribution License (CC BY). The use, distribution or reproduction in other forums is permitted, provided the original author(s) and the copyright owner(s) are credited and that the original publication in this journal is cited, in accordance with accepted academic practice. No use, distribution or reproduction is permitted which does not comply with these terms. 